\title{
Evaluation of the effect of Ni-P coating on the corrosion resistance of the aluminium 7075 T6 alloy ${ }^{(*)}$
}

\author{
L., Gil* , L Jiménez*, A.C. Castro**, E.S. Puchi-Cabrera** and M. H. Staia**
}

\begin{abstract}
The aluminum alloy 7075-T6 is a structural alloy widely used for aeronautical applications due to its high relationship between mechanical resistance and weight. Depending upon the environmental conditions, many types of corrosion mechanisms such as intergranular, exfoliation, have been found to occur in aircraft structural aluminum alloys. A significant advance in order to improve the behavior of this alloy is related to the application of the autocatalytic $\mathrm{Ni}$-P coating which confers an excellent corrosion resistance coupled with both reduced erosive wear and higher hardness. The purpose of this work was to investigate the effect of the application of a Ni-P coating on the corrosion resistance of an aluminum 7075-T6 alloy. The results obtained indicated that the application of the Ni-P coatings diminishes the susceptibility to pitting and makes the aluminum $7075 \mathrm{~T} 6$ alloy immune to the exfoliation corrosion attack.
\end{abstract}

\section{Evaluación del efecto de la aplicación de un recubrimiento de Ni-P sobre la resistencia a la corrosión de la aleación de aluminio 7075 T6}

Resumen

Palabras Claves

\begin{abstract}
La aleación de aluminio 7075-T6 es una aleación estructural ampliamente utilizada para aplicaciones aeronáuticas, debido a su alta relación entre resistencia mecánica y peso. Dependiendo de las condiciones ambientales, algunos mecanismos de corrosion tales como intergranular, exfoliacion, picadura y crevice se ha encontrado que ocurren en estructuras de aviones de aleaciones de aluminio. Un avance siginificativo para mejorar el comportamiento de esta aleación es la aplicación de recubrimientos autocatalíticos de Ni-P, los cuales confieren una excelente resistencia a la corrosión acoplado con una reducción del desgaste erosivo y un aumento de la dureza. El propósito de este trabajo fue investigar el efecto de la aplicación de un recubrimiento de Ni-P sobre la resistencia a la corrosión de una aleación de aluminio 7075-T6. Los resultados obtenidos indican que la aplicación del recubrimiento de Ni-P disminuye la susceptibilidad a la picadura y hace a la aleación de aluminio 7075 T6, prácticamente inmune al ataque por corrosion expoliación.
\end{abstract}

Aluminio 7075 T6. Electroless Ni-P. Corrosion. Exfoliación. Picadura

\section{INTRODUCTION}

Amongst the materials required by the aerospace industry, which are generally characterized by an improved toughness, lower weight and an increased resistance to fatigue and corrosion, the aluminum alloy 7075 T6 occupies an important place. The 7xxx series alloys were all designed to emphasize strength, which came at some cost to damage tolerance and corrosion performance ${ }^{[1]}$. Indeed, the 7075 T6 alloy exhibits a high susceptibility to stress corrosion cracking $^{[2}$ and 3$]$, which is the main mechanism of failure caused by the presence of pits acting as stress concentrators. Another type of damage frequently found in airplanes, and common to this alloy, is due to the corrosion-exfoliation phenomenon which takes place mainly in the riveted zones, where the corrosive electrolyte could easily penetrate and reach the metallic structure.

\footnotetext{
(·) Trabajo recibido el día de 15 de Enero y aceptado en su forma final el día 25 de Enero de 2007.

* Departamento de Ingeniería Metalúrgica, Universidad Nacional Experimental Politécnica (UNEXPO), Puerto Ordaz, Venezuela, lindagil@cantv.net

** Escuela de Ingeniería Metalúrgica y Ciencia de los Materiales, Facultad de Ingeniería, Universidad Central de Venezuela, Apartado 49141, Caracas 1042-A, Venezuela, mhstaia@cantv.net.
} 
In order to improve the corrosion and erosive wear performance of this alloy and to upgrade its life expectation a significant advance was achieved by depositing electroless (EN), which is able to confer uniform coating thickness all over the component surface $^{[4]}$. The most employed EN coatings are $\mathrm{Ni}-\mathrm{P}$ based alloys which are produced by the autocatalytic reduction of nickel cations from an aqueous solution using a variety of reducing agents. The choice of reducing agent dictates the alloys composition, e.g., sodium hypophosphite for Ni-P alloys. The composition of the alloy strongly influences its properties and is controlled by adjusting the $\mathrm{pH}$, nickel concentration and temperature ${ }^{[5}$ and 6$]$.

Electroless Ni-P coatings are widely used for corrosion protection applications in a variety of environments as it acts as a barrier coating protecting the substrate by sealing it off from the corrosive environments, rather than by sacrificial action. Recently, much attention has been given to the corrosion behavior of $\mathrm{Ni}-\mathrm{P}$ coatings and their characteristics including the content and distribution of phosphorus, as well as surface morphology and structure $^{[7 \text { and } 8]}$. Low-phosphorus deposits (1 to 3 percent $\mathrm{P}$ ) are crystalline and exhibit good wear resistance, but relatively poor corrosion resistance in a chloride environment. Medium phosphorus deposits ( 5 to 8 percent $P$ ) have a smaller crystallite size, whereas high-phosphorus deposits (more than 10 percent) exist mainly as a metallic glass. Mediumphosphorus deposits usually have properties lying between the low and high phosphorus deposits, but the solutions offer enhanced deposition rates. Highphosphorus deposits typically exhibit the best corrosion properties, but suffer from slow rates of deposition.

The corrosion resistance of the electroless Ni-P coating depends on several factors namely the phosphorus content, degree of cristallinity, size and orientation of the grains, phase and structural variation and the thickness and coating porosity. According to Mimani and Mayanna ${ }^{[6]}$, the corrosion behavior of electroless $\mathrm{Ni}-\mathrm{P}$ coatings is governed by three principal factors such as the degree of amorphous state, the extent of internal stress and the percentage of phosphorus content. The study of the performance of these coatings in different environments as a function of different phosphorus content is addressed by several researchers ${ }^{[6}$ and $\left.9-13\right]$. Raicheff and Zaprianova ${ }^{[10]}$ have suggested that the higher corrosion resistance of amorphous electroless $\mathrm{Ni}-\mathrm{P}$ coatings is due to their homogeneous structure and the absence of grain boundaries, dislocations, kink sites and other surface defects. Lu and Zangari ${ }^{[9]}$ have also suggested that the difference in corrosion resistance between electroless $\mathrm{Ni}-$ low $\mathrm{P}$ and $\mathrm{Ni}$-high $\mathrm{P}$ coatings is in part due to the difference in structure- a crystalline, inhomogeneous structure for the low $\mathrm{P}$ content materials, and an amorphous, homogeneous one for the high $\mathrm{P}$ content materials.

Bai et al. ${ }^{[11]}$ have suggested that the $\mathrm{P}$ content of the electroless $\mathrm{Ni}-\mathrm{P}$ coating has a positive effect on reducing the corrosion rate and on shifting positively the corrosion potential in chlorine media. Diegle et al. ${ }^{[14]}$, Lu and Zangari ${ }^{[9]}$, Lee and Liang ${ }^{[12]}$ and Aoki and Takano ${ }^{[13]}$ have also pointed out that electroless Ni-P coatings with higher $\mathrm{P}$ content show nobler $\mathrm{E}_{\text {corr }}$ and lower $\mathrm{i}_{\text {corr }}$ values and potentially better corrosion resistance. Besides structure and homogeneity, electronic effects are also considered to be responsible ${ }^{[9]}$. It has been pointed out that the $\mathrm{P}$ in the amorphous $\mathrm{Ni}-\mathrm{P}$ coating acts as an acceptor and gains 0.4-0.8 electrons from $\mathrm{Ni}$ with increasing $\mathrm{P}$ content between 13 and 25 at. \% ${ }^{[15]}$. The corresponding partially covalent character of the $\mathrm{Ni}$-P bonding arrangement influence the equilibrium involved in $\mathrm{NiO}$ formation and $\mathrm{Ni}$ dissolution.

The formation of an adsorbed film of hypophosphite generated by the oxidation of phosphorus present in the coating surface, which in turn blocks the water molecules from interacting with nickel thus inhibiting nickel oxidation, is considered to be one of the most convincing models ${ }^{[14]}$ proposed to explain the difference in corrosion behavior of electroless $\mathrm{Ni}-\mathrm{P}$ coatings. According to this model, preferential dissolution of nickel occurs even at the open circuit potential, leading to the enrichment of phosphorus on the surface layer. The enriched phosphorus surface reacts with water to form a layer of adsorbed hypophosphite anions $\left(\mathrm{H}_{2} \mathrm{PO}_{2}^{-}\right)$. This layer in turn will block the supply of water to the electrode surface, thereby preventing the hydration of nickel ${ }^{[14]}$, which is considered to be the first step to form either soluble $\mathrm{Ni}^{2+}$ species or a passive nickel film. Van Der Kouwe ${ }^{[16]}$, using glow discharge optical emission spectrometry, confirmed the presence of a phosphorus rich surface layer in a high phosphorus ( $8 \mathrm{wt} . \% \mathrm{P}$ ) electroless nickel deposit even before it is subjected to any corrosive environment. Accordingly, such a condition of phosphorus enrichment at the surface provides a competitive advantage for the hydrolysis of phosphorus and would not favor the hydrolysis of nickel. Hence, the better corrosion resistance obtained for electroless Ni-high P coatings is due to the enrichment of phosphorus on the electrode surface, a condition which is not favored in electroless $\mathrm{Ni}$-low and medium P coatings. Since electroless $\mathrm{Ni}$-low $\mathrm{P}$ coating is crystalline and electroless $\mathrm{Ni}$ medium P coatings is not totally amorphous, the passive films that form on the surface these coatings 
are not as glassy or protective as that of the one formed on electroless high-P coatings. The phase boundaries present in low and medium $\mathrm{P}$ coatings also produce passive film discontinuities, which are preferred sites for corrosion attack to begin.

The Ni-P electroless coating has been widely studied on steel substrates which exhibited poor tribological and corrosion performance, resulting in an improvement in these properties with the application of the coating. Nevertheless, its behavior on aluminum alloys has been little studied. Therefore, the purpose of the present research is to investigate the corrosion behavior of a high phosphorus $\mathrm{Ni}-\mathrm{P}$ coatings on Al 7075 T6 substrate in $3 \%$ aqueous $\mathrm{NaCl}$, using an electrochemical techniques and standard tests to determine its exfoliation corrosion resistance.

\section{EXPERIMENTAL PROCEDURE}

The Ni-P coatings were deposited industrially (Reliable Plating Inc., USA) onto an aluminum 7075-T6 substrate. The coatings have a high phosphorus content (11 wt \% P), a thickness of 65 microns and an approximate density of $8.1 \mathrm{~g} / \mathrm{cm}^{3}$.

The electrochemical techniques used in the present work include the linear polarization, potentiodynamic polarization and the cyclic polarization. The anodic potentiodynamic polarization measurements were performed using a Gamry PC4/750 Potentiostat/Galvanostat Model DHC2 (Gamry Instruments, Inc. USA). A neutral solution containing $3.0 \% \mathrm{NaCl}$ in de-ionized water was used as the electrolyte. The solution was purged with nitrogen gas during the test. A stabilization period of $3600 \mathrm{~s}$ was employed before starting the measurement. The electrode potential was raised from $-0.25 \mathrm{mV}$ to $1.6 \mathrm{mV}$ with the rate of $1.0 \mathrm{mV} / \mathrm{s}$ and the current that flowed through the coatingsubstrate system was recorded. $\mathrm{An} \mathrm{Ag} / \mathrm{AgCl}$ electrode was used as the reference electrode and graphite as the counter electrode. An EG\&G K105 flat specimen holder was used. It has to be reminded that the experiment was carried in such a way that the electrolyte was in contact only with the coated surface. The contact area in all cases was of $0.54 \mathrm{~cm}^{2}$.

The potentiodynamic cyclic polarization technique ${ }^{[17]}$ is an accelerated electrochemical corrosion test which is employed to evaluate the localized corrosion resistance of many alloys and coatings. In this test, specimens are anodically polarized in a corrosive medium and the potential is increased in the positive direction up to a point where a certain value of resulting current is reached. At this point, the potential is decreased and both the applied potential and resulting current are plotted. The breakdowns potential $\left(\mathrm{E}_{\mathrm{pit}}\right)$ at which accelerated corrosion occurs and the size of the hysteresis loop formed during the reverse scan are two important measures of both the pitting or crevice corrosion resistance of the sample, respectively. A higher breakdown potential and a smaller hysteresis loop indicate a good corrosion resistance.

The potential scans for the cyclic polarization tests were initiated at $-250 \mathrm{mV}$ vs. the corrosion potential of sample $\left(\mathrm{E}_{\text {corr }}\right)$ and ended at $0 \mathrm{mV}$. A potential scan rate of $0.28 \mathrm{mVs}^{-1}$ was used and scans were reversed once the transpassivity potential was exceeded. In this test, values of the pitting potential $\left(\mathrm{E}_{\mathrm{pit}}\right)$ and protection potential $\left(\mathrm{E}_{\text {prot }}\right)$ were determined. $\mathrm{E}_{\text {pit }}$ is the potential where the breakdown of passivity occurs and it is marked by the rapid increase in the current density due to pit initiation and growth.

The exfoliation corrosion resistance of electroless Ni-P coated specimens and 7075-T6 alloy substrate were evaluated according to the ASTM G-34-72 standard $^{[18]}$ in a $4 \mathrm{M} \mathrm{NaCl}, 0.5 \mathrm{M} \mathrm{KNO}_{3}$ and $0.1 \mathrm{M}$ $\mathrm{HNO}_{3}$ solution at $25^{\circ} \mathrm{C}$. The test solution is very corrosive and is meant to represent a more severe type of the environment exposure. The usual practice to evaluate the extent of damage due to exfoliation corrosion is to assign a visual rating with reference to standard photographs ${ }^{[18]}$.

The linear polarization experiments were carried out by scanning the potential $\pm 10 \mathrm{mV}$ about to open circuit potential $\left(\mathrm{E}_{\text {corr }}\right)$ a rate of $1 \mathrm{mVs}^{-1}$. The polarization resistance values $\mathrm{Rp}(\mathrm{E} / \mathrm{I})$ were evaluated from this plot. The corrosion current density $\left(\mathrm{I}_{\text {corr }}\right)$ was calculated using the equation

$$
i_{\text {corr }}=\frac{\beta_{a} \beta_{c}}{2.303\left(\beta_{a}+\beta_{c}\right)} \frac{1}{R_{p}}
$$

Where, $\beta_{\mathrm{a}}$ and $\beta_{\mathrm{c}}$ where experimentally determined. The corrosion rate (mpy) was estimated by

$$
m p y=\frac{i_{\text {corr }} M W}{n F \rho}
$$

where it was assumed that: MW, (molecular weight), was $53.44 \mathrm{~g} / \mathrm{mol}$ (based on the coating composition), $\mathrm{n}$ was 2 equiv/mol, $\mathrm{F}$ is Faraday's constant, and $\rho$ (density), was $8.1 \mathrm{~g} / \mathrm{cm}^{3}$. Combining equations (1) and (2) and applying the appropriate conversion factors, the corrosion rate was related to the charge transfer resistance by the following relationship: 


$$
m p y \approx \frac{18292}{R_{p}}
$$

Equation (3) provides an estimated of the corrosion rate. The corrosion rate was calculated from $\mathrm{R}_{\mathrm{p}}$ to supply a semiquantitative measure of the relative changes in its magnitude.

The microstructure and morphological characteristics of the coatings before and after the corrosion tests were examined by using a scanning electron microscope (Phillips XL30 SEM) coupled with a standard energy dispersive X-ray microanalysis attachment (EDAX-DX4). The XRD patterns for the electroless Ni-P coatings were produced by using a Siemens b-500 X-ray diffractometer-Cu ka radiation. The specimen was scanned through $2 \theta$ angles of $25^{\circ}-65^{\circ}$.

In addition to the electrochemical technique, surface composition of the corroded samples was obtained using a Jeol JAMP 8100 Auger electron microprobe.

\section{RESULTS AND DISCUSSION}

\subsection{Microstructure and morphology}

Scanning electron micrographs (BSE) of as plated electroless Ni-P coated specimens microstructure are in figures $1 \mathrm{a}$ ) and $1 \mathrm{~b}$ ). As can be observed, a smooth homogeneous surface is present with morphological characteristics similar to those previously found for the amorphous $\mathrm{Ni}-\mathrm{P}$ alloy $[8,19$ and 20$]$. The variation in surface morphology of these coatings suggests a definite dependence on their phosphorus content, supporting the observations made by Lu and Zangari [9] who indicated that electroless $\mathrm{Ni}$-high $\mathrm{P}$ and $\mathrm{Ni}$-medium $\mathrm{P}$ coatings exhibit a smooth surface with uniform particle size, whereas a relatively rough surface composed of spherical particles of varying sizes is observed for electroless Ni-low P coating. The appearance of cauliflower-like nodules (at higher magnifications), which is typical for an amorphous coating, is observed for electroless $\mathrm{Ni}$-high $\mathrm{P}$ content.

Figure 2 shows the XRD pattern of the as-plated electroless $\mathrm{Ni}$-P alloys coating. It can be seen clearly that only one broadening peak appears in the spectrum and this coating is regarded as having an amorphous structure. Similar results have been reported in the literature ${ }^{[6}$ and 8$]$ indicating that electroless deposits with phosphorous contents more than approximately $8 \mathrm{wt} \%$ are essentially amorphous. The broadening of the peaks is mainly attributable

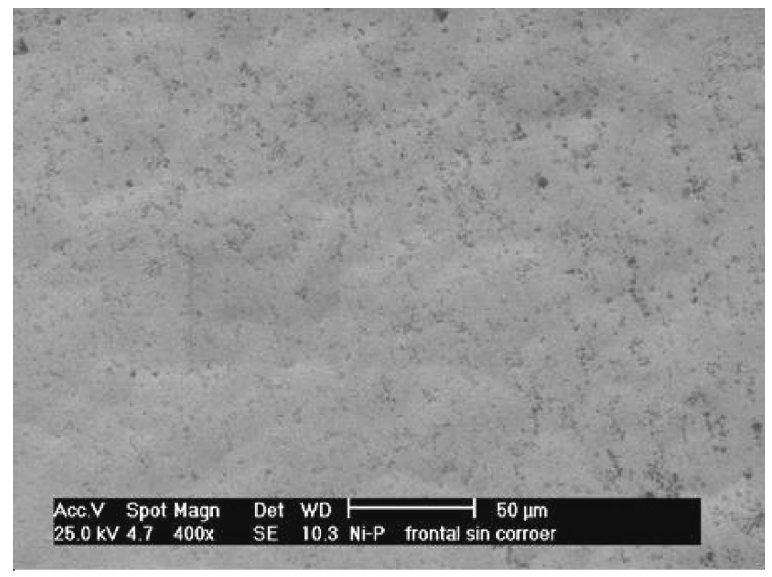

a)

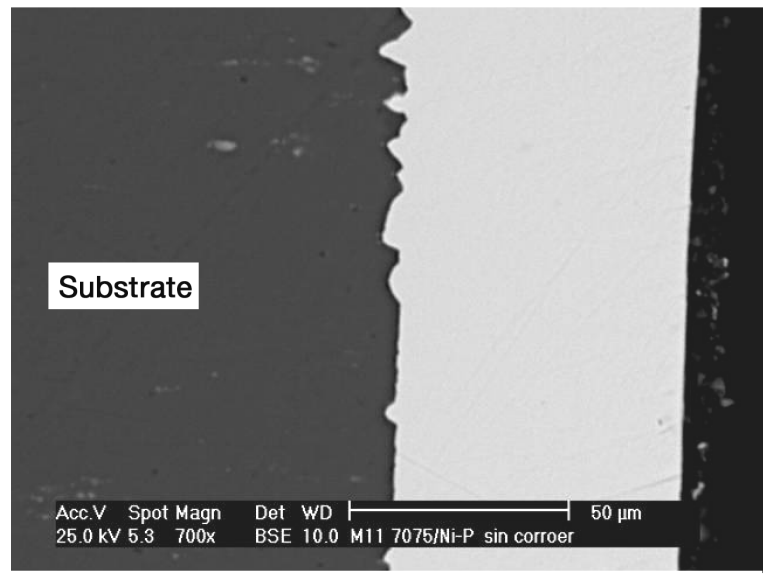

b)

Figure 1. SEM micrographs showing the as-deposited Ni-P coating morphologies: a) Top view. b) Cross-section.

Figura1. Fotomicrografías obtenidas por MEB indicando la morfología del recubrimiento Ni-P como depositado: a) Vista frontal. b) Sección transversal .

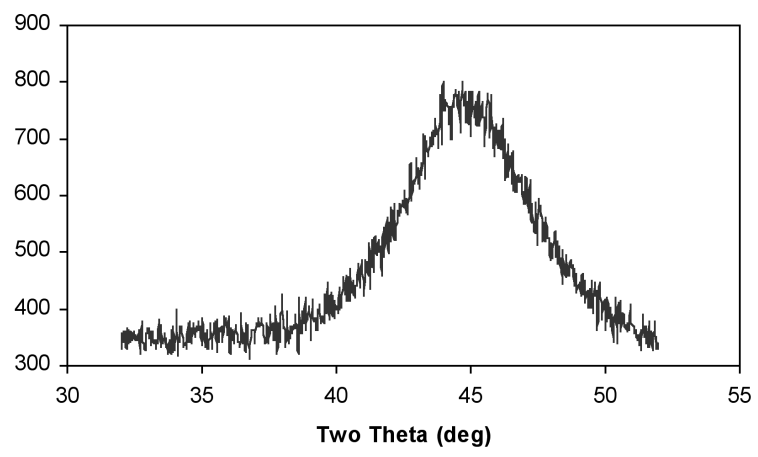

Figure 2. XRD pattern of the electroless Ni-P alloys coating.

Figura 2. Patrón de DRX de la aleación recubierta con electroless Ni-P. 
both to microstress and nanocrystalline structure or amorphous structure of Ni-P films being supersaturated with respect to phosphorus ${ }^{[21]}$.

\subsection{Corrosion behavior}

Figure 3 shows the potentiodynamic polarization response of both electroless $\mathrm{Ni}$-P coating and 7075 T6 substrate in deaerated neutral $3.0 \mathrm{wt} \% \mathrm{NaCl}$ solutions. As it can be observed the coated system shows a better corrosion resistance than the 7075 -T6 substrate alone indicating thus the beneficial effect due to the presence of the coating. The corrosion potential $\left(\mathrm{E}_{\text {corr }}\right)$ value was shifted towards a more positive potential and the corrosion current density $\left(i_{\text {corr }}\right)$ value decreased when the coating was present. In general, an amorphous electroless $\mathrm{Ni}$ P coating has a better corrosion resistance than 7075 . T6, because it does not have surface inhomogeneities (grain boundaries and second-phase particles) which are active sites for corrosion attack and this result is in agreement with those found by others investigations $^{[6 \text { and 19]. Flis and Duquette }}{ }^{[22]}$ studied the effect of phosphorus on the anodic behaviour of electroless $\mathrm{Ni}$-P alloy in near-neutral and alkaline solutions. They showed that the addition of phosphorus enhanced the dissolution rate relative to that of pure nickel, while the anodic dissolution decreased when the phosphorus content was increased

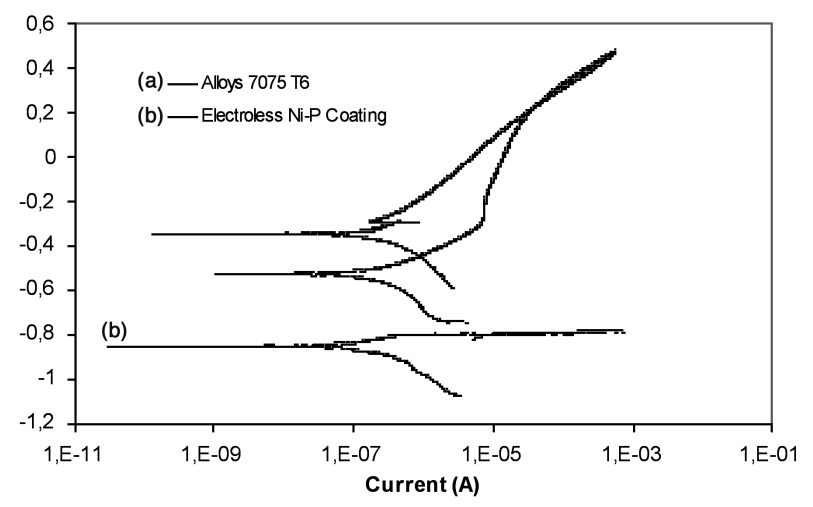

Figure 3. Potentiodynamic polarization curves of the electroless Ni-P coating and 7075-T6 alloy substrate in deaerated neutral $3.0 \mathrm{wt} \%$ $\mathrm{NaCl}$ solution.

Figura 3. Curvas de polarización potenciodinámica de la aleación con recubrimiento de electroless Ni-P y del sustrato de la aleación 7075 T6 en una solución neutra desaireada de $\mathrm{NaCl}$ al $3 \%$ en peso. from 2.9 to $12.3 \%$. They concluded that the detrimental effect of phosphorus on the corrosion resistance of nickel is associated with a lower protectiveness of the film, whereas the beneficial effect at higher phosphorus contents is associated with the formation of a phosphate film.

Diegle and co-workers ${ }^{[14]}$, have investigated the passivity of amorphous $\mathrm{Ni}-20 \% \mathrm{P}$ alloy in acidic electrolytes and proposed a chemi-passivity model to explain the passivation process of $\mathrm{Ni}-20 \mathrm{P}$, which is controlled by the formation and adsorption of hypophosphite anions ( $\left.\mathrm{H}_{2} \mathrm{PO}_{2}^{-}\right)$, these form a barrier layer between the alloys and the electrolyte, preventing the hydration of nickel atoms at the electrode surface by inhibiting mass transport of water through the film. Zeller ${ }^{[5]}$ investigated the corrosion behaviour of $\mathrm{Ni}-\mathrm{P}$ in $5 \% \mathrm{NaCl}$ and proposed a protection mechanism in which the formation of the phosphorus-enriched layer may result in a suppressed cathodic reaction, decreasing the overall corrosion rate.

In a neutral $\mathrm{NaCl}$ solution (Fig.3), the anodic polarization curve of the $\mathrm{Ni}$-P electroless coating can be divided into two regions. Firstly, for potentials between $\mathrm{E}_{\text {corr }}$ and approximately $0.2 \mathrm{~V}(\mathrm{Ag} / \mathrm{AgCl})$, the dissolution of the Ni-P alloys was kinetically limited where the anodic current density increased slowly with potential. Secondly, at potentials above $0.2 \mathrm{~V}$, the Ni-P alloy began to dissolve transpassively. The anodic potentiodynamic polarization curves were similar to those previously published for amorphous $\mathrm{Ni}$-P alloy in chloride-containing solutions ${ }^{[5,6}$ and 19 21]. On the other hand, the aluminum 7075-T6 polarization curve shows a typical behavior of an active-passive metal, with a rapid increase of current $\left(\mathrm{E}_{\text {pit }}\right)$ about -0.812 vs. $\mathrm{E}_{\text {corr }}$. The rapid increase in the current value is due tobreakdown of the passive films at localized imperfections. This phenomenon is commonly known as pitting corrosion ${ }^{[3]}$ and the potential at which a rapid increase occurs is usually termed the "pitting potential or breakdown potential" $\left(\mathrm{E}_{\mathrm{pit}}\right.$ or $\left.\mathrm{E}_{\mathrm{bk}}\right)$.

The cyclic polarization behavior of electroless $\mathrm{Ni}$ $\mathrm{P}$ coating and 7075-T6 substrate in deaerated neutral $3.0 \mathrm{wt} \% \mathrm{NaCl}$ solution are compared in figure 4 . The values for the corrosion potential, $\left(\mathrm{E}_{\text {corr }}\right)$, pitting corrosion $\left(\mathrm{E}_{\mathrm{pit}}\right)$, protection potential $\left(\mathrm{E}_{\mathrm{prot}}\right)$ and corrosion current density $\left(\mathrm{i}_{\text {corr }}\right)$ are indicated in table I. The degree of hysteresis in the scan indicates that the electroless coating sample did not show neither pitting behavior no a rapid increase in current during the forward potential scan. In this case, the reverse scan closely followed the forward scan and very a small hysteresis loop was observed during the reversed scan. The current density values obtained 


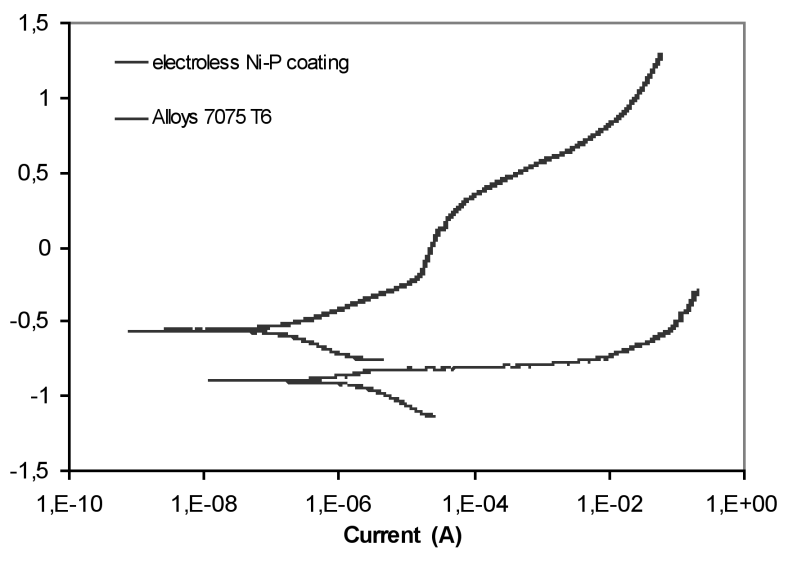

Figure 4. Potentiodynamic cyclic polarization curves of the electroless Ni-P coating and 7075T6 alloy substrate in deaerated neutral $3.0 \mathrm{wt}$ $\% \mathrm{NaCl}$ solution.

Figura 4. Curvas de polarización cíclica potenciodinámica del recubrimiento electroless Ni-P y del sustrato de aleación 7075 T6 en una solución neutra desaireada de $\mathrm{NaCl}$ al $3 \%$ en peso.

were very low. Since there were no pits, the corrosion of the coating at a given potential remained the same during the reverse scan. The sample, thus, demonstrated an excellent corrosion resistance.

According to the literature related to the corrosion resistance of materials ${ }^{[23]}$ there are three criteria that can be met by the exposed material of interest to the corrosion environment. The first criteria states that if $\mathrm{E}_{\text {corr }}$ is equal to or greater than the protection potential $\left(\mathrm{E}_{\text {prot }}\right)$, both pitting and crevice type of corrosion attack of the specimen are possible. The second criteria sates that if $\mathrm{E}_{\text {corr }}$ is less than the protection potential $\left(\mathrm{E}_{\text {prot }}\right)$, a pitting type of corrosion attack of the specimen in unlikely to occur. The third criteria states that if the repassivation potential $\left(\mathrm{E}_{\text {prot }}\right)$ is grater than $\mathrm{E}_{\text {corr }}$, a crevice type of corrosion is not possible. Based on the discussion above for pitting criteria, the figure 4 , shows that amorphous electroless $\mathrm{Ni}-\mathrm{P}$ coatings have pitting resistance when they are exposed to a chloride medium. These results correlate well with the results obtained in earlier studies ${ }^{[5,6}$ and 8$]$, which indicate that amorphous electroless Ni-P (high P content) coatings are expected to have better corrosion resistance due to the absence of interfaces and grain boundaries, excluding the possibility of pitting.

Pitting tendencies can also be assessed from the "pitting potential " $\left(\mathrm{E}_{\mathrm{pit}}\right)$ indicated in Fig 4. If $\mathrm{E}_{\mathrm{pit}}$ is close to $\mathrm{E}_{\text {corr }}$, little polarization is required to initiate the pits formation. Thus, samples more prone to pitting will have relatively low $\mathrm{E}_{\text {pit }}-\mathrm{E}_{\text {corr }}$ values. Table 1 summarizes the $E_{\text {pit }}-E_{\text {corr }}$ values for coated and uncoated samples. This table indicates that the electroless $\mathrm{Ni}$-P coated samples are less prone to localized corrosion.

The corrosion exfoliation behavior of electroless $\mathrm{Ni}-\mathrm{P}$ coating and 7075-T6 substrate in solution are compared in figure 5. As it can bee observed the aluminum 7075-T6 alloy was susceptible to exfoliation corrosion phenomenon. The exfoliation rating (damage level) according to the ASTM G-34-72 standard was of an EB moderate type. On the other hand, electroless Ni-P coated samples showed practically no corrosive attack.

It this type of corrosion, attack proceeds along selective sub-surface paths parallel to the surface. As shown in figure 5 , layers of uncorroded metal between the selective paths are split apart and pushed above the original surface by the voluminous corrosion products formed along the paths of attack. Because it can be detected readily at an early stage and is restricted in depth, exfoliation does not cause unexpected structural failure, as does SCC ${ }^{[24]}$.

Table I. Electrochemical parameters estimated from polarization tests of the electroless Ni-P coating and 7075 T6 alloy substrate in deaerated neutral $3.0 \mathrm{wt} \% \mathrm{NaCl}$ solutions.

Tabla I. Parámetros electroquímicos estimados de los ensayos de polarización de la aleación de aluminio 7075 T6 y de la aleación recubierta con electroless Ni-P en una solución neutra desaireada de $\mathrm{NaCl}$ al $3 \%$ en peso.

\begin{tabular}{|c|c|c|c|c|c|c|c|}
\hline Sample & $\begin{array}{c}E_{\text {corr }} \\
(V)\end{array}$ & $\begin{array}{l}E_{p i t} \\
(V)\end{array}$ & $\begin{array}{c}E_{\text {prot' }} \\
(V)\end{array}$ & $\begin{array}{c}i_{\text {corr }} \\
\left(\mu \mathrm{A} / \mathrm{cm}^{2}\right)\end{array}$ & $\begin{array}{l}\text { Corrosion } \\
\text { rate (mpy) }\end{array}$ & $\begin{array}{c}\text { Rp } \\
\text { (KOhms) }\end{array}$ & $\begin{array}{c}E_{p i t}-E_{c o r r} \\
(V)\end{array}$ \\
\hline \multirow{2}{*}{$\begin{array}{l}7075 \text { T6 Alloy } \\
\text { Electroless Ni-P } \\
\text { coating }\end{array}$} & -0.85 & -0.81 & -0.82 & 3.17 & 1.4 & 1.52 & 0.04 \\
\hline & -0.53 & 0.16 & 0.27 & 0.38 & 0.3 & 72.84 & 0.7 \\
\hline
\end{tabular}




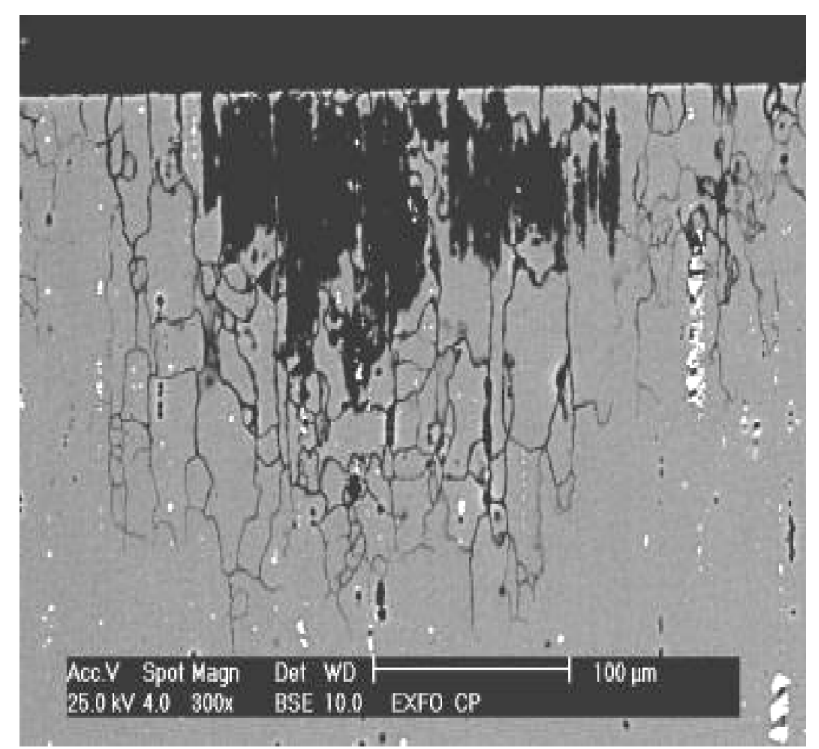

a)

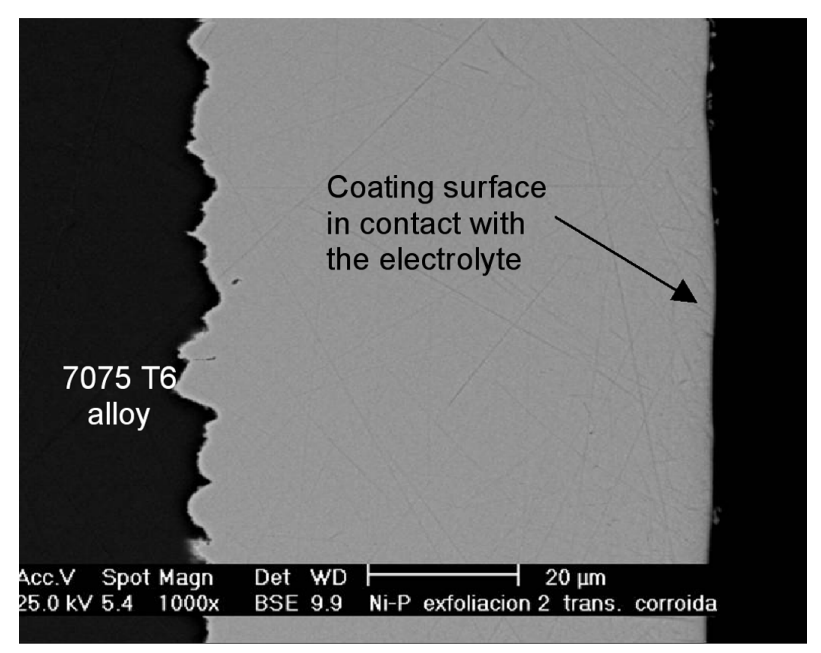

b)

Figure 5. SEM micrographs of the cross-section of the corroded samples after the exfoliation corrosion tests. a) Al 7075 T-6 alloy substrate; b) Ni-P coated substrate.

Figura 5. Fotomicrografías por MEB de la sección transversal de la muestra corroída después del ensayo de corrosión exfoliación. a) Sustrato de aleación de Al 7075 T6; b) Sustrato recubierto con Ni-P.

\subsection{Post-tests analysis of samples}

The morphology of the corroded sample was examined using a scanning electron microscope as shown in figure 6. No significant pitting attack is observed on the electroless nickel coated Al 7075T6 sample corroborating then the results obtained from the electrochemical experiments.
Auger Electron Spectroscopy (AES) analysis of the corrosion products was carried out for electroless $\mathrm{Ni}-\mathrm{P}$ coating after the polarization measurements performed in $3.0 \% \mathrm{NaCl}$. (Fig.7). AES analysis revealed the presence of $\mathrm{Ni}$ and $\mathrm{O}$ suggesting the existence of an oxide layer on the coating surface. Similar results as those presented in this paper were reported by Zeller and Salvati ${ }^{[24]}$.

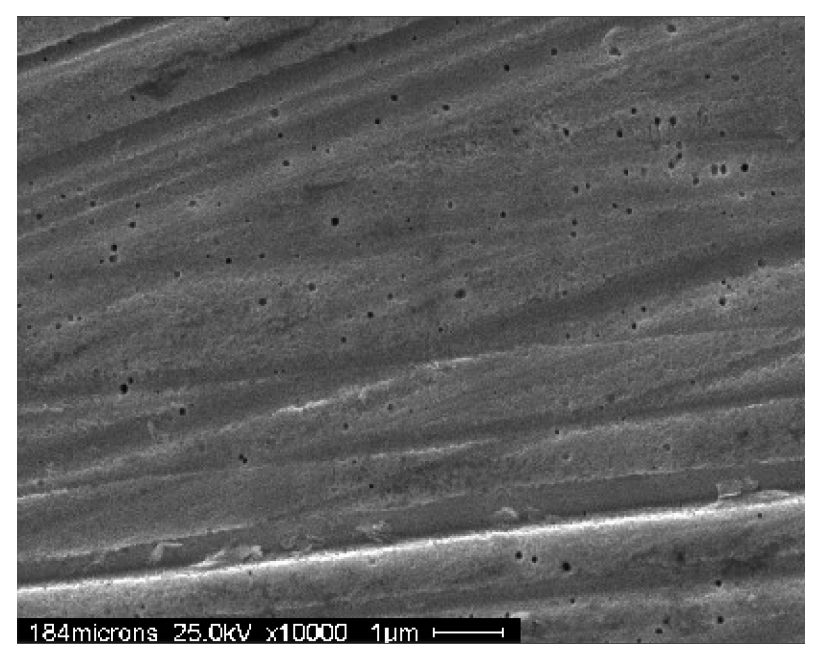

Figure 6. SEM micrograph of the corroded Ni-P alloy coating samples after cyclic polarization test (Top view).

Figura 6. Fotomicrografía por MEB de la muestra corroída de la aleación recubierta con Ni-P después del ensayo de polarización cíclica (vista frontal).

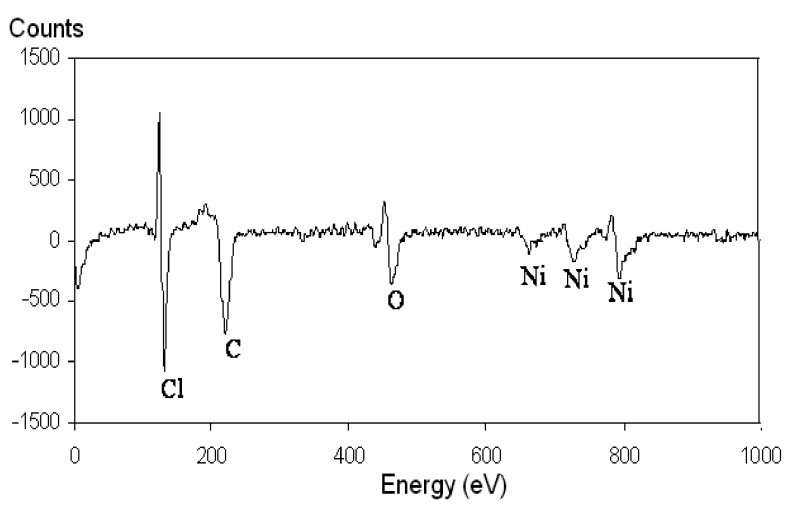

Figure 7. AES analysis of corrosion products of electroless Ni-P coating sample in $3.0 \%$ wt $\mathrm{NaCl}$.

Figura 7. Análisis por espectroscopia Auger de los productos de corrosión de la muestra recubierta con $\mathrm{Ni}-\mathrm{P}$ en $\mathrm{NaCl}$ al 3 \% en peso. 
EVALUATION OF THE EFFECT OF NI-P COATING ON THE CORROSION RESISTANCE OF THE ALUMINIUM 7075 T6 ALLOY EVALUACIÓN DEL EFECTO DE LA APLICACIÓN DE UN RECUBRIMIENTO NI-P SOBRE LA RESISTENCIA A LA CORROSIÓN DE LA ALEACIÓN DE ALUMINIO 7075 T6

\section{CONCLUSIONS}

The electroless Ni-P coating was found to have an amorphous-like structure. Potentiodynamic and cyclic polarization curves for electroless $\mathrm{Ni}$-P coating in 3 $\% \mathrm{NaCl}$ solution revealed a significant decrease in the anodic current density and a positive shift of the corrosion potential with the application of the coating on the Al 7075 T-6 substrate indicating an excellent corrosion resistance of the coated samples. The corrosion rates of high phosphorous electroless $\mathrm{Ni}-\mathrm{P}$ coating $(11 \%)$ is very low $(0.3$ mpy) in $3 \% \mathrm{NaCl}$ indicating that this coating is a good candidate for its application in this environment. The electroless $\mathrm{Ni}$-P coated samples remained practically without the presence of an exfoliation corrosion attack.

\section{Acknowledgments}

The authors wish to acknowledgments the financial support received from Venezuelan National Found for Science, Technologicy and Innovation (FONACIT) through the project G-2000001591

\section{REFERENCES}

[1] R. BucCI AND C. WARren, J. Aircr. 37 (2000) 122-129.

[2] J. Badía, J. Antoranz, P. TARín, A. SimÓn AND N. M. PIRIS, Rev. Metal. Madrid 40 (2004) 436-442

[3] E. STANSBURY AND R. BUCHANAN, Fundamentals of Electrochemical Corrosion, Ed. ASM International, 1th edition, Materials Park, Ohio, USA, 2000, pp. 297-305.

[4] C. Dervos, P. VAssiliou AND J. NovaKovic, Rev. Metal. Madrid 41 (2005) 232-239.

[5] R. ZELLER III, Corrosion 47 (1991) 692-702.

[6] T. Mimani And S. Mayanna, Surf. Coat. Technol. 79 (1996) 246-251.

[7] P. Lo, W. Tsai, J. Lee and M. Hung, Surf. Coat. Technol. 67 (1994) 27-34.
[8] N. Martyak, S. Wetterer, L. Harrison, M. MCNeIl, R.Heu AND A. Albert NeIderer, Plat. Surf. Finish 6 (1993) 60-64.

[9] G. LU AND G. ZANGARI, Electrochim. Acta 47 (2002) 2969-2979.

[10] R. RaicheFF AND V. Zaprianova, J. Mater. Sci. Lett. 19 (2000) 3-5.

[11] P. BAI, Y. ChuANG AND C. Hu, Mater. Chem. Phys. 82 (2003) 93-100.

[12] S. Lee And H. Liang, Plat. Surf. Finish. 78 (1991) 82-86.

[13] K. Aoki And O. Takano, Plat. Surf. Finish. 73 (1986) 136-141.

[14] R. Diegle, N. Sorensen, C. Clayton, M. Helfand AND Y. YU, J. Electrochem. Soc. 135 (1988) 1085-1092.

[15] Y. OKAMATO, Y. NitTA, T. IMANAKA AND S. TERANishi, J. Catal. 64 (1980) 397-404.

[16] E. VAn Der KouWe, Electrochim. Acta 38 (1993) 2093-2097.

[17] ASTM 661-686, Conducting Cyclic Potentiodynamic Polarization Measurements for Localized Corrosion Susceptibility of Iron, Nickel, or Cobalt-Based Alloys, ASTM, 1988, West Conshohocken, PA, USA.

[18] ASTM 634-672, Exfoliation Corrosion Susceptibility in 7 XXX Series Copper-Containing Aluminum Alloys (EXCO Test), ASTM, 1972, West Conshohocken, PA. USA.

[19] Z. Longfei, L. Shufu And L. PengXing, Surf. Coat. Techn. 36 (1988) 455-462.

[20] J. Carbajal and R. White, J. Electrochem. Soc. 135 (1988) 2952-2957.

[21] H. Ashassi-SORKHABI AND S. RAFIZADEH, Surf. Coat. Technol. 176 (2004) 318-326.

[22] J. Flis AND D. DUQUETTE, Corrosion 28 (1972) 321-330.

[23] R. BABOIAN, Electrochemical Techniques for Corrosion Engineering, Ed. NACE, Houston, TX, USA, 1986.

[24] R. Zeller III AND R. SAlvati, Corrosion 50 (1994) 457-467). 